\title{
日本学術会議は 時代とともに
}

目邻立述会議

私が日本学術会議会員を務めた 3 期 9 年間を振 り返ると、激しい時代の動きと、それに対応する 日本学術会議の側の意識の激しい变遷の様子がま ざまざと蘇ってくる。日本学術会議は確かに日本 の学界と政界、官界、社会との接触の場であり、 世界の学界との対応の拠点として大きな役割を演 じてきた。この役割は今後とも続くし、むしろま すます重要となるだろう。将来への期待と危惧を こめて、印象の深い出来事を振り返ってみたい。

\section{国際対応の14期（1988-1991）}

私にとってこの期の主要課題は国際対応であっ た。私は1988年から国際学術連合 (ICSU：現・国 際科学会議) の総務委員となり、いわゆるビザ問題 に直面した。当時アパルトヘイト政策をとってい た南アフリカ連邦の科学者が日本に入国するとき、 「自分は人種差別主義者ではなく、そのような主義 の団体にも属さない」との文章が印刷されたビザ 申請書に記入し署名させていた。これがICSUの科 学の普遍性の原理に違反するとICSUの科学者の自 由交流委員会が指摘していたが、1988年のICSU総 会を日本が招致しようとしたのをきっかけに問題 が顕在化しだ”。

ICSUでは、日本がビザ申請書の誓約文を削除す るか、あるいは誓約文のついた申請書をICSU総会 への出席者全員に差別なく使用するならば、日本 の招致を受け入れてもよいと内々いってきた。日 本学術会議の保証でそのようになれば有り難いの 
だが、このままでは、ICSUの総会だけでなく、その 傘下の国際会議すべてが日本では開けなくなるので 困ると外務省に嘆願しても、事情を察してくれる少 数の人は別として、国連決議を何と心得るかと相手 にされなかった。ICSUに対しては、ICSUに資金を 出しているユネスコは国連の機関だから、両方の方 針が食い違うのはおかしいのではないかと何度も指 摘した。しかし、自分たちの立てた科学の普遍性の 原理が一番優先するという理屈で、しかもヨーロッ パにはそれを支持する国々が多くて、こちらは孤立 した。

そうこうしているうちに総会は中国にもっていか れてしまい、1988年、当時の近藤次郎会長ととも にいささかやるせない思いで北京を訪れた。実は、 ノルウェーでは国際免疫学会を計画していたとこ ろ、政府筋が南アフリカの科学者は一人も入国させ ないと言明したために、ICSUの勧告で開催地が急 遽トルコに移されてしまった。それで，北京の総会 では怒ったノルウェーの委員が中心になって、 ICSUの科学者の自由交流委員会を批判する動きが でて緊迫した。しかし、頼みのアフリカ諸国の委員 たちの論旨もあまり鋭くはなく、科学者の自由交流 委員会への攻撃はうやむやに終わった。

この問題は、アパルトへイトの停止が間もないと 予想される頃になって、ビザ申請書の誓約文が削除 されてけりがついたが、割り切れない気持ちを後に 残した。これは原理原則を重んずる西欧と、実際へ の適応を重んずる日本の文化の摩擦ともいえる出来
事である。原理原則を守るためには自己の不利益に も耐える姿勢が必要であり、無原則な対応に終始す ることは後に禍根を残すことになると思い知った。

\section{国際貢献の第15期（1991-1994）}

第15期の頃には、日本の経済力が増大し、バブ ル経済のため過大評価さえされた。それで、今まで の発展を助けてもらった抢礼に世界の発展に貢献し たいという空気が日本に充満した。多額の援助資金 を世界にばらまきながら、どうしたら日本の気持ち が世界に理解されるかを論じた時代である。要する に、戦後外国からの影響に受け身にばかり対処して きたのが、そろそろ、主体的に外国に対して働きか けたいという日本人の願望を現していたと私は解釈 している。何かをしたい、そのための経済力もあ る、しかし何をすれば的確か、それがわからない、 というフラストレーションに国中が陥つていたよう な気がする。

1991年10月の総会を訪れた坂本三十次内閣官房 長官が、学術の分野における国際貢献はどのように すればよいかを考えるようにと検討を依頼した。当 時の渡邊格副会長を委員長に学術国際貢献特別委員 会が作られ、総会でも討論を重ねだ2。何か画期的 な提案が生まれれば素晴らしいと期待したのだが、 議論はひどく難航し、委員会の報告書は中身のはっ きりしない新システムの提案に終わってしまった。 これらの議論から生まれた唯一の具体的成果は、ア ジア学術会議ではないかと思う。 
過去に学ぶという意味で、私の率直な意見をいう と、国際貢献にかこつけて、日本学術会議の活動を 拡大することばかり考え過ぎた。日本学術会議が何 をするかをばかり議論していて、日本全体で何をす べきかという議論にならなかった。何か事業を構想 しても、それが日本学術会議の手におえるような範 囲のものでなければ意味がなかった。そのような枠 の中で一体何ができるだろうか。私が第16期の会長 を務める時には、この反省を貴重な教訓とした。

私にとって、学術に拁ける国際貢献の一番よい 例はヒューマン・フロンティア・サイエンス・プロ グラムである。10年前に当時の中曽根首相が $G 7$ の国々を語らい、フランスのストラースブルグに設 立した研究助成機関である。毎年の助成総額は約 40 億円で、1989年から1999年までの10年間に1571の 研究室に研究費を支援し、1246 名の若い研究者に フェローシップを与えた。助成を受けた者の中から ノーベル医学生理学賞あるいは化学賞の受賞者が5 人もでている。先進国の基金を集めて基礎的な生物 学、神経科学の分野で高水準の国際的、学際的研究 を助成するという考えはユネスコにも、個別の先進 国にもなかった発想で、ある外国人が極めて独創的 と称賛するのを聞いた。そのような賛辞を受ける独 創的な計画がもっと日本の学界からでてもよいと思 うし、またそれを高く評価する空気が国内にもっと あってもよいはずである。

\section{科学技術政策の第16期（1994-1997）}

1994年に始まる過去の5年間は、わが国の科学技 術政策の上に大きな変化があった時期である。私は 1994年10月二国間交流事業で訪れたロンドンで、 冷戦終結後の軍事から科学技術へ向けての世界的な 大きな地滑りを肌身に感じ、世界の科学技術を巡る 状況が大転換しつつある凄まじさに目を見張った。 このことが1995年4月の総会における戦略研究の提 案に導いた。この概念は科学技術研究に国の経常経 費だけでなく、投資経費をも当てようとの国会での 動きの理論的基盤ともなり、現在年間 600 億円を超 す投資的研究費の支出に繋がった。

1996年の科学技術基本法の制定に当たっては、私 の関心は研究者の希望が最大に盛り込まれることで あった。1997年の最初の科学技術基本計画の策定 に当たっては、わが国の研究システムを研究者の立 場から見直して、その改善策を盛り込むよう、利谷 信義、西島安則両副会長、各部の部長をはじめ多く の会員の方々のバックアップをいただいて、日本学 術会議の努力を結集した。当時の基調講演や討議資 料の内容を読み直してみると、その後改善策の対象 となったことがほとんど指摘されている。

第1回の科学技術基本計画の中で提案された研究 費倍増計画、つまり平成8年から12年までの5年間 に17兆円の政府研究費を投資する計画は、補正予 算を含めて達成の方向にある。現在すでに、第2回 の科学技術基本計画の策定準備が始まっているが、 
次の 5 年間には総額 23 兆円の政府研究費の投下が政 治の話題になっている ${ }^{5)}$ 。ポストドクター1万人計 画もほぼ達成され、2 万人計画が議論されている。 第1回の基本計画では、これまでの研究体制の不備 を指摘し改善策を提案することが主体であったが、 次の基本計画ではもっと積極的な発展策が盛られる ことであろう。

\section{脳科学の展開}

こういう全体的な動きの中で、より具体的な各論 のレベルでの進展をはかるべく、第16期には脳の科 学とこころの問題をテーマに大熊輝男会員を委員長 をとする特別委員会が審議し、戦略研究のモデルと して脳科学の特段の推進を要請する政府勧告を1996 年に行った。当時の橋本龍太郎首相が訪口中だった ので、梶山静六内閣官房長官に勧告文をもっていっ て渡したが、これが各省庁に渡され、科学技術庁を はじめ、幾つかの省庁で脳科学関連の事業が始まっ た。平成11年度の脳科学関連の政府研究費は総額 265億円にまで伸びた。

私は1997年7月、日本学術会議の任期を満了した が、同年10月に理化学研究所に脳科学総合研究セ ンターが開所して、その所長を務めることになっ た。戦略研究としての脳科学の研究推進計画の中核 として設立されたもので、「脳を知る、守る、創る」 の3目標に向けて、理工系 (物理、化学、工学) と生 物系 (医学、生物学、農学) の学際的な統合を目指 している点が、世界的に新機軸として注目されてい
る。平成11年7月現在、29研究室、研究者と研究支 援者を合わせて312名の組織である。所員は全員契 約雇用され、研究者の平均年齢は34歳である。研 究者と研究支援者の比率はほぼ2対 1 で、第1回の 科学技術基本計画で勧告された線を実現したのは日 本広しといえども此処だけである。もう一つの大き な特徴として、外国人 79 名 $(25 \%)$ が 21 力国から参 加しており、うち研究室主任 (チームリーダー) が4 名いて、国際化の実をあげている。

理研脳科学総合研究センターは、最近提案されて いる生命科学の次世代型研究機関のモデルになって いる。私としてはこの新しい試みは 21 世紀における 日本の研究システム全体の成否を占うものになると 考え、その成功に向けて努力している。第16期に懸 命に考え、提案したことのフォローアップをしてい る気持ちである。
参考文献
1）伊藤正男 日本学術会議の国際対応 UP21巻3号14-21頁、1991
2) 伊藤正男 国際貢献一何をどういしたらよいのか。 日本学術会議月報 34巻8号1993
3）伊藤正男 高度研究体制の早期確立を目指して 学術の動向 1 巻1号 1995
4) 伊藤正男 我が国の学術研究体制は如何にあるべきか 学術の動向 1 巻 1 号 1995>
5 ）加藤紘一 今政治は何をすべきか一新世紀日本の設計図 講談社

伊藤 正男（いとう まさお 1928年生）

第16期日本学術会議会長、理化学研究所脳科学総合研究センター 所長、東京大学名誉教授、日本学士院会員、医学博士 専門: 生理科学 